\title{
EXAMPLES OF TRAFFIC NOISE ABATEMENT IN THE CITY OF OSIJEK
}

\author{
Martina Zagvozda \\ Josip Juraj Strossmayer University of Osijek, Faculty of Civil Engineering Osijek, mag.ing.aedif. \\ Corresponding author: mzagvozda@gfos.hr \\ Hrvoje Dragovan \\ Institut IGH d.d., mag.ing.aedif. \\ Vesna Dragčević \\ University of Zagreb, Faculty of Civil Engineering Zagreb, Full Professor
}

\begin{abstract}
Noise pollution is a major environmental problem in urban spaces worldwide. The first step toward noise abatement is determining and evaluating noise levels in order to best prioritize and implement protective measures. The city of Osijek, as is obligated by law and the European Directive, has done this by creating a noise map. In this paper, we present measures for noise abatement, showing some of the measures implemented in Osijek based on their noise map, and review possible methods for abating noise in the most vulnerable areas.
\end{abstract}

Keywords: noise abatement, noise maps; noise barriers; Osijek

\section{MJERE ZA SMANJENJE PROMETNE BUKE NA PRIMJERU GRADA OSIJEKA}

Sažetak: Zagađenje bukom danas je jedan od glavnih, u svijetu prisutnih problema zagađenja okoliša i urbanog prostora. Prvi korak ka smanjenju razina buke je utvrđivanje i ocjena razina buke kako bi se mogli definirati prioriteti za provedbu mjera zaštite. Grad Osijek, budući da je dužan prema Zakonu o zaštiti od buke i Direktivi Europskog parlamenta, izradio je kartu buke koja prikazuje razine buke i njihovu prostornu distribuciju. Ovaj rad prikazuje mjere za zaštitu od buke te neke od mjera provedene u gradu Osijeku i, na osnovu stanja utvrđenog kartom buke, razmatra mogućnosti provedbe mjera za zaštitu od buke najugroženijih područja.

Ključne riječi: smanjenje buke; karte buke; barijere za zaštitu od buke; grad Osijek 


\section{INTRODUCTION}

Environmental noise pollution is recognized worldwide as one of the main factors reducing the quality of life in urban areas [1]. Environmental noise is defined as "unwanted or harmful outdoor sound created by human activities, which includes the noise emitted by forms of transport, road traffic, rail traffic, air traffic, and the location of industrial activities" [2]. Noise is also acoustic energy, described by the sound pressure level in units of decibels $[\mathrm{dB}(\mathrm{A})]$. Many studies have shown that noise is harmful to human physiology and psychology $[3,4]$. The World Health Organization has estimated that $40 \%$ of Europeans are exposed to harmful noise levels [5], and the annual cost from noise pollution in the European Union is 40 billion euros [6].

To protect its citizens and reduce noise, in 2002 the European Union adopted European Directive 2002/49/EC [2], whose main objective was to avoid, prevent, and reduce harm from environmental noise. To accomplish this goal, the directive recommended various actions, including determining noise levels by source and number of people exposed, creating noise maps, informing people and raising awareness, and defining measures and strategies for noise abatement and preservation of quiet areas.

The greatest cause of noise pollution, especially in urban areas, is widespread motor vehicles. To prevent further pollution and reduce noise to satisfactory levels, various measures of noise abatement must be used. However, implementing noise abatement in dense urban areas is difficult: urban space is expensive and scarce, and abatement solutions must be integrated into the existing built environment.

In this paper, we present measures for noise abatement and their use in the city of Osijek. Assessing a noise map of Osijek from 2014, we show the city's current state of noise pollution without an action plan, and we consider possible ways to abate noise in the most vulnerable areas.

\section{MEASURES FOR NOISE ABATEMENT}

Noise abatement can be achieved primarily through prevention or reduction of noise at the source. Secondary measures reduce noise propagation and block sound at the emission source. Economic measures and regulations can also affect noise levels by introducing fees that fund research, development, and implementation of noise-protection measures [7]. The following is a brief review of possible noise-protection measures.

\subsection{Reducing noise generation}

In urban areas with low driving speeds, the dominant source of noise is the vehicle engine, whose design is regulated and restricted by Directive 70/157 / EEC [7]. Further noise abatement is possible by reducing noise created by wheels rolling on the pavement through construction and traffic management measures. Traffic can be managed by reducing traffic volume and the share of heavy vehicles, reducing speed, and changing driving styles (passive driving) [8]. Construction measures-such as implementing low-noise pavement [7, 9] and constructing roundabouts [8]-are expensive, best applied to new or reconstructed roads. Speed bumps can reduce noise by reducing vehicle speed, but can also increase noise from vehicles accelerating after the bumps.

The noise generated by tram and rail traffic depends on the track structure, vehicle type, and condition of the riding surface $[7,10]$. For this traffic, measures to reduce noise include strict control and maintenance, using double elastic mounts, wooden sleepers, concrete slabs for closing tram rails, and newer vehicles [11].

\subsection{Reducing noise propagation}

Noise propagation can be reduced by barriers and by spatial planning and management: ensuring that residential areas are far from noise sources, planning buildings or facilities less susceptible to noise to be near the road [7], and placing buffer zones of trees and shrubs between roads and buildings [12].

In urban areas where existing noise must be reduced, noise barriers are the most common and most effective solution. Noise barriers are long, thin walls that prevent sound waves from propagating along a straight path between the emission and imission points and eliminate the impact of the part of the sound wave reflected from the pavement. When designing such barriers, their dimensions and location should be optimized by acoustic calculations. Additionally, these barriers must be stable and mechanically sound, made of materials appropriate 
for the climate and location. Noise barriers can be reflective-bouncing sound waves without reducing their intensity-or absorptive, absorbing much of the sound energy and reflecting only a small part. To satisfy all these criteria, barriers can be constructed of various materials including concrete, metals, wood, brick, plastic, and various recycled materials [12].

Experiences from the city of Zagreb show that if the requirements of the location are respected in design, barriers can considerably reduce noise while fitting in well with the environment [13, 14]. Research and development of RUCONBAR at Department of Transportation of Civil Engineering Faculty in Zagreb show that barriers can be constructed in a innovative way that is both effective in noise protection and preserves the environment by utilizing waste materials such as old tires [15]. For noise protection from city rail and tram traffic, short barriers placed next to the source are appropriate because they create less visual interference [16].

\subsection{Protecting against noise at the imission site}

If other measures are insufficient, costly, or impractical, existing noise can be reduced at the imission site. This is done by integrating sound insulation into existing buildings and suitably designing new buildings [7].

\section{TRAFFIC NOISE IN THE CITY OF OSIJEK}

\subsection{Noise mapping}

To reduce noise and create an action plan for a given area, it is first necessary to determine the noise levels and their causes. A noise map shows the current and/or anticipated conditions of noise emission, expressed by the harmonized noise indicators $L_{\text {den }}$ and $L_{\text {night. }}$. They show where noise exceeds the limit, estimates the number of people exposed to various noise levels, and estimates the number of dwellings, schools, and hospitals exposed to certain noise indicator values $[17,18]$. The limits of immision noise for spaces in which people work and live are $55 \mathrm{~dB}(\mathrm{~A})$ and $45 \mathrm{~dB}(\mathrm{~A})$ for the day and night, respectively, prescribed by state ordinance on the maximum permitted noise level [19].

All cities with more than 100,000 inhabitants and the concessionaires of industrial areas, major roads, major railways, and major airports are required by law on noise protection [17] to create noise maps with noise differentiated by source. These noise maps show the current state of environmental noise, along with its sources and magnitudes, and the mechanisms of noise propagation, as well as any existing barriers to noise propagation. Using a noise map, an action plan can be developed that defines ways to abate existing noise, prevent further increases in noise, and enable future space planning in order to create so-called quiet areas.

\subsection{Noise pollution}

The city of Osijek, as required by law [17], has taken the first step toward noise abatement by creating a noise map [20]. These noise levels were determined by measuring noise for 150 days and creating 3D models. The noise map shows the noise levels in the city during all times of day $\left(L_{\text {day }}, L_{\text {evening, }} L_{\text {night }}\right)$ and the daylong noise by the indicator $L_{\text {den. }}$. Also, the noise level can be viewed by cause: road, tram, or rail transport and industry.

The main source of noise in Osijek is traffic. City traffic mainly consists of intercity road traffic, the south and west bypass, tram traffic, and the rail passing through the city (Figure 1). 


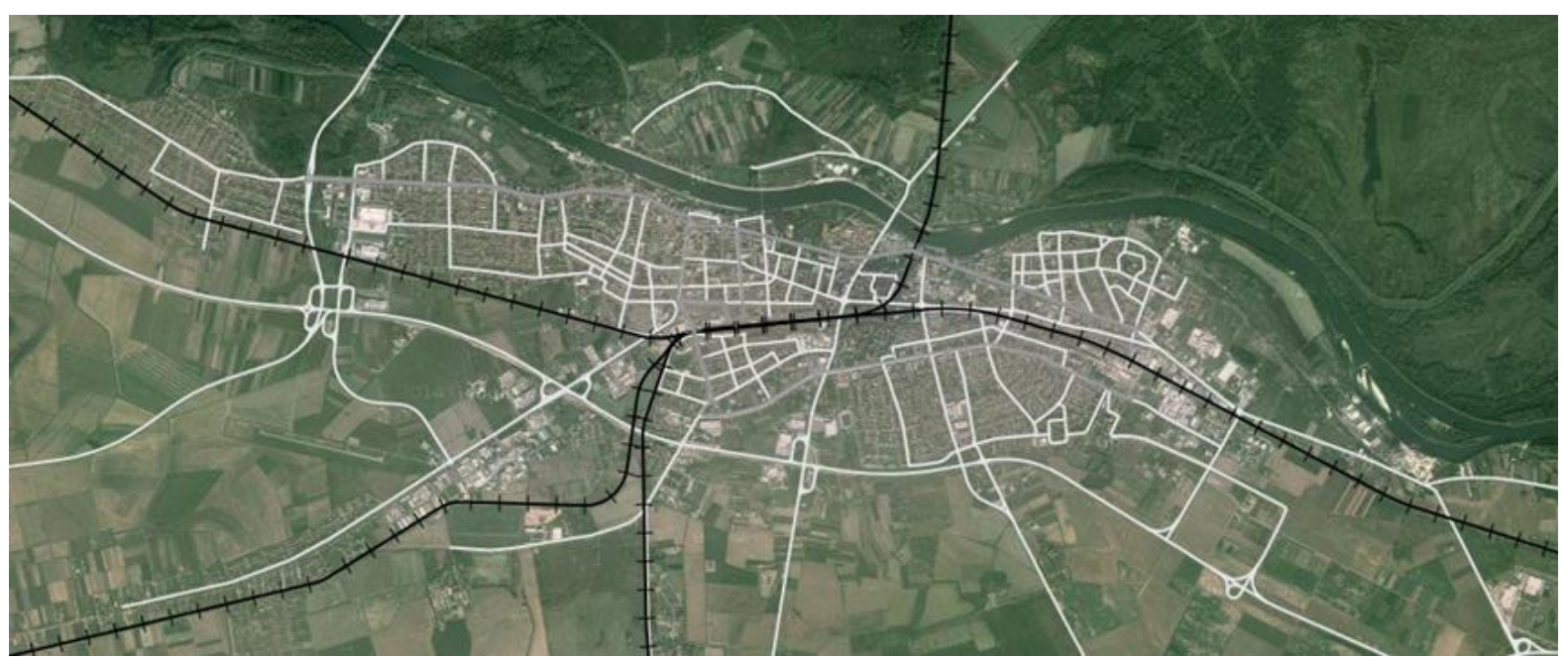

Figure 1 Traffic network of Osijek

Road transport with the longest traffic network affects the greatest number of people by the noise it produces. Noise levels shown through $L_{\text {den }}$ exceed $55 \mathrm{~dB}$ in most residential areas, climbing to $70-80 \mathrm{~dB}$ in areas surrounding streets with high traffic volume (Figure 2). Even at night, noise levels are much higher than permissible: the larger city streets have noise levels as high as $65-70 \mathrm{~dB}$. The streets with the most traffic noise are also the busiest city roads, which connect the city in longitudinal and transverse directions, linking areas on the verge of the city and the suburbs (Figure 2).

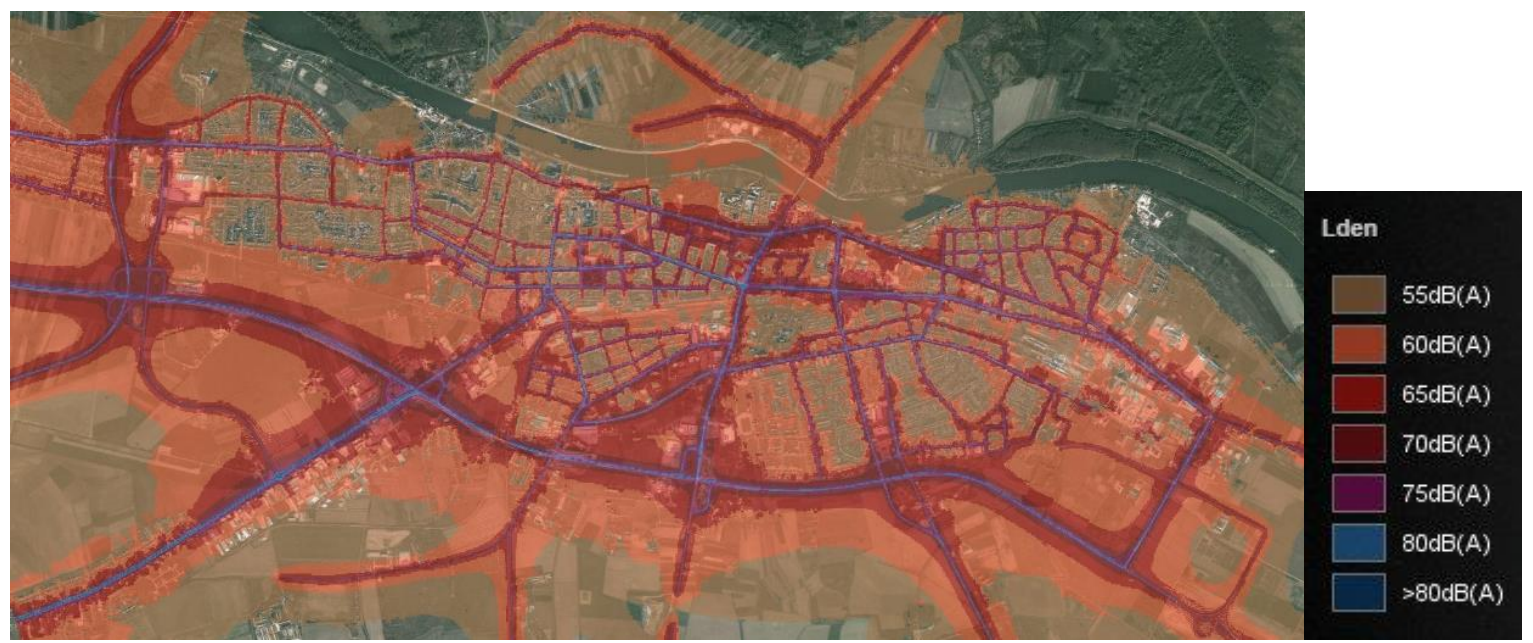

Figure 2 Daylong $\left(L_{\text {den }}\right)$ noise levels from road traffic

Rail transport creates noise levels of $80 \mathrm{~dB}\left(L_{\text {den }}\right)$ near the rail station and west entrance to the city, and during night these levels decrease by only $5-10 \mathrm{~dB}$ ( $\left.L_{\text {night }}\right)$. Trams cause noise of $60-65 \mathrm{~dB}$ during the day and 55 $\mathrm{dB}$ at night.

Although the noise from industry exceeds permitted levels, it is mostly located on the city outskirts, or the plants are designed to be far from the nearest residential area and have their own perimeter facilities that reduce noise propagation. 


\section{NOISE ABATEMENT MEASURES IN OSIJEK}

\subsection{Existing noise abatement measures}

For many years, noise abatement measures have been built on Croatian highways, but the problem of noise in urban areas has not been systematically considered. In recent years, to better match the regulations with the European Union, align with new laws, and meet increasing complaints from residents, more attention is being paid to noise pollution, planning, and protection. The city of Zagreb has excelled in this, building walls in multiple locations $[13,14]$ and conducting research on reducing noise $[11,15]$.

Osijek, however, had not yet created systematic plans for noise abatement, and many roads in the city produce noise exceeding regulated limits [19]. Along some streets with heavy traffic, green belts have been created that reduce noise somewhat, but reducing noise was not their primary task. The one or two rows of trees and shrubs are not sufficient to significantly reduce noise.

So far in Osijek, the only physical noise protection planned and built is on the western bypass at the junction with the Višnjevac suburbs (Figure 3, left): a noise barrier build from metal pillars with transparent and wooden panels. Transparent panels were used on the overpasses, and wooden panels were used in areas where the barrier rests on the embankment. On the eastern side, the barrier only covers the overpass because it is meant to protect the industrial/business zone; on the west side, next to the Višnjevac suburbs, the barrier is much longer because it protects the residential areas. Figure 3 shows this wall and its effect on the noise map.

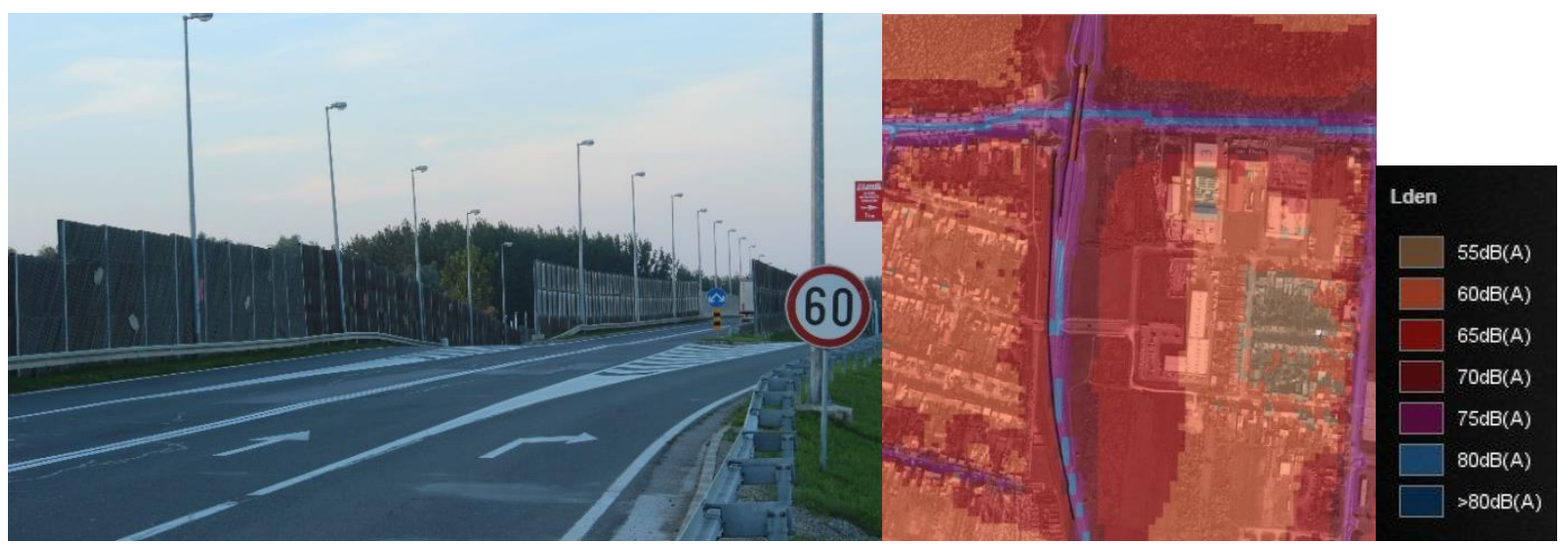

Figure 3 a) Noise barrier on west bypass and b) the effect of the noise barrier on noise levels

Many residents near the southern bypass are complaining of noise. Protection is needed here because there are residential areas near roads with a traffic load of 18500 vehicles per day, composed almost $17 \%$ of heavy vehicles. Because of this, and because traffic will continue to increase, the largest amount of noise protection in Osijek yet is being constructed during the construction of the southern pavement of the southern bypass. In this project, noise barriers will be constructed at nine locations with a total length of $4368 \mathrm{~m}$; at three of these locations, the noise barriers will cover both sides of the road. The protection is designed to last for 15 years, and its sound insulation must exceed $25 \mathrm{~dB}$. The barrier is designed to protect residential areas in locations where the road passes close by, whether on embankments or on other structures such as overpasses. On embankments, light concrete panels are being constructed; on overpasses and underpass, the barriers will be made of transparent panels between steel columns separated by $4 \mathrm{~m}$ [21]. Figure 4 shows a barrier during construction. 


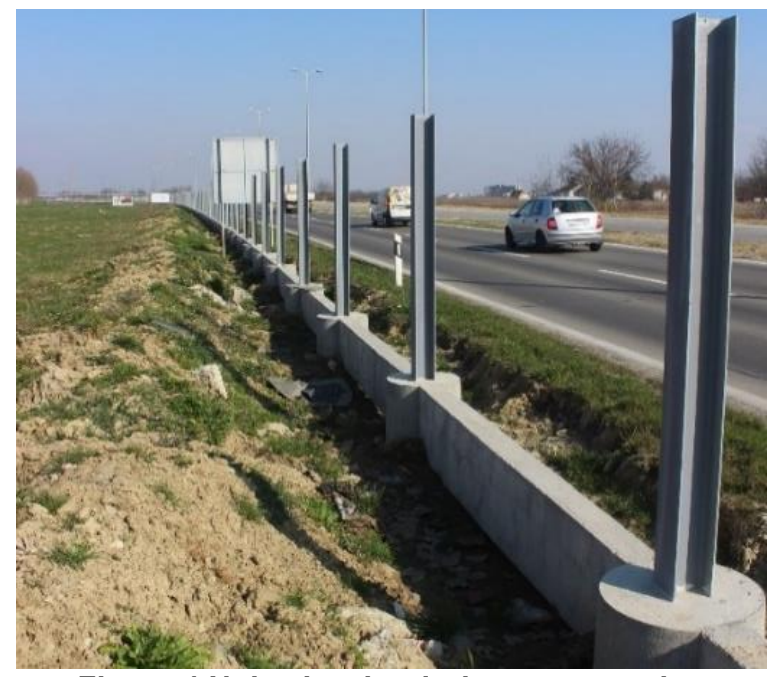

Figure 4 Noise barrier during construction

Noise has been reduced in some parts of the city through other measures not focused on noise reduction, such as speed limits, traffic bans on certain types of vehicles, and suitable urban planning. For example: the streets in the old part of the city, Tvrđa, are paved with small stone cubes, which can generate considerable noise. Noise has been limited here through several measures introduced because of safety, pavement structure, and capacity. Some of the traffic areas, along with a central square, have been turned into pedestrian-only zones, while in other parts the car speed has been limited to $30 \mathrm{~km} / \mathrm{h}$ and trucks and heavy vehicles have been prohibited (Figure 5, left). The high noise levels of European Avenue, located south of Tvrđa, have been attenuated by a green belt, but they have been reduced more so by the massive buildings around the perimeter. Figure 5 shows a noise map of the area, revealing the effect of these measures. It should be noted that these noise maps do not include noise from bars and clubs, though this noise can dominate on the weekends during the evening and night.

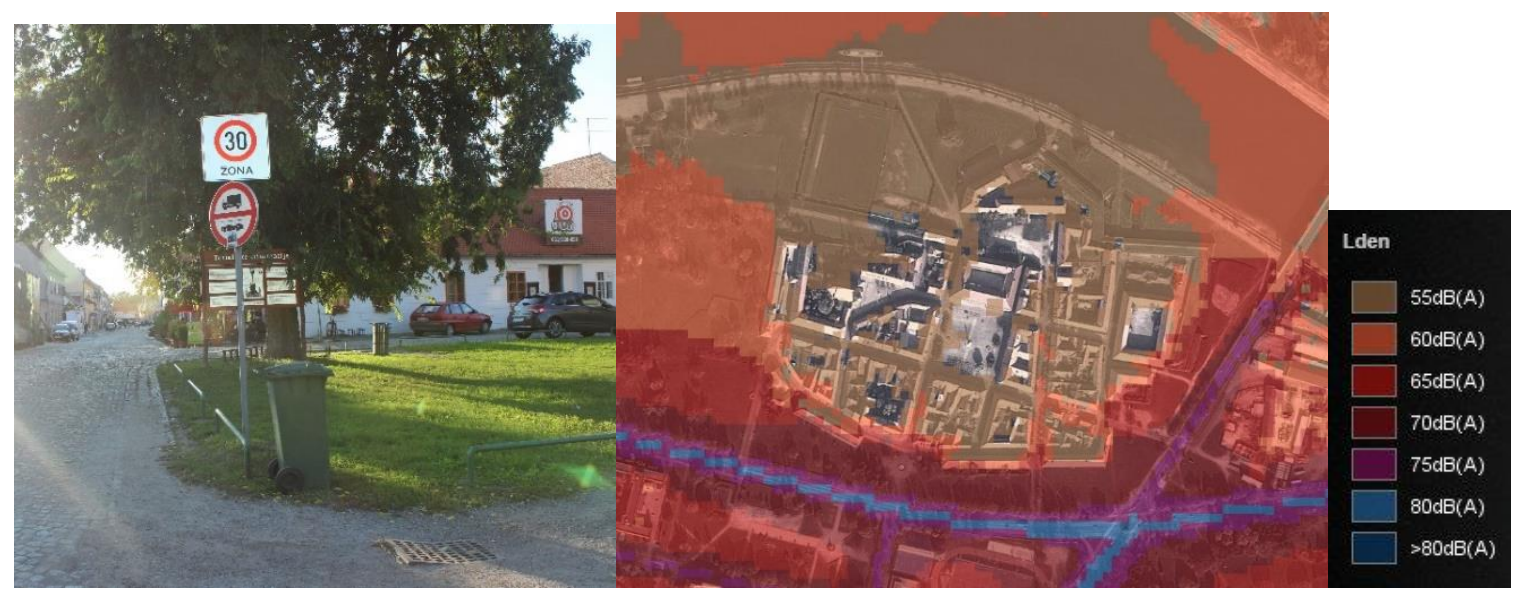

Figure 5 a) Noise abatement measures and b) noise levels in Tvrđa

There are more positive examples of considering noise problems during urban planning in Sjenjak (Figure 6) and Vijenac Ivana Mestrovica. Green areas and parking constructed in front of residential buildings create offset from roads and attenuate the surrounding traffic noise by $20-25 \mathrm{~dB}(\mathrm{~A})$. Such design of urban space creates silent areas (Figure 7) with noise below permitted limits. Noise can be further limited by reducing speed limits for safety reasons. Driving speed is lowered by horizontal alignment, in addition to traffic signs and speed bumps. 

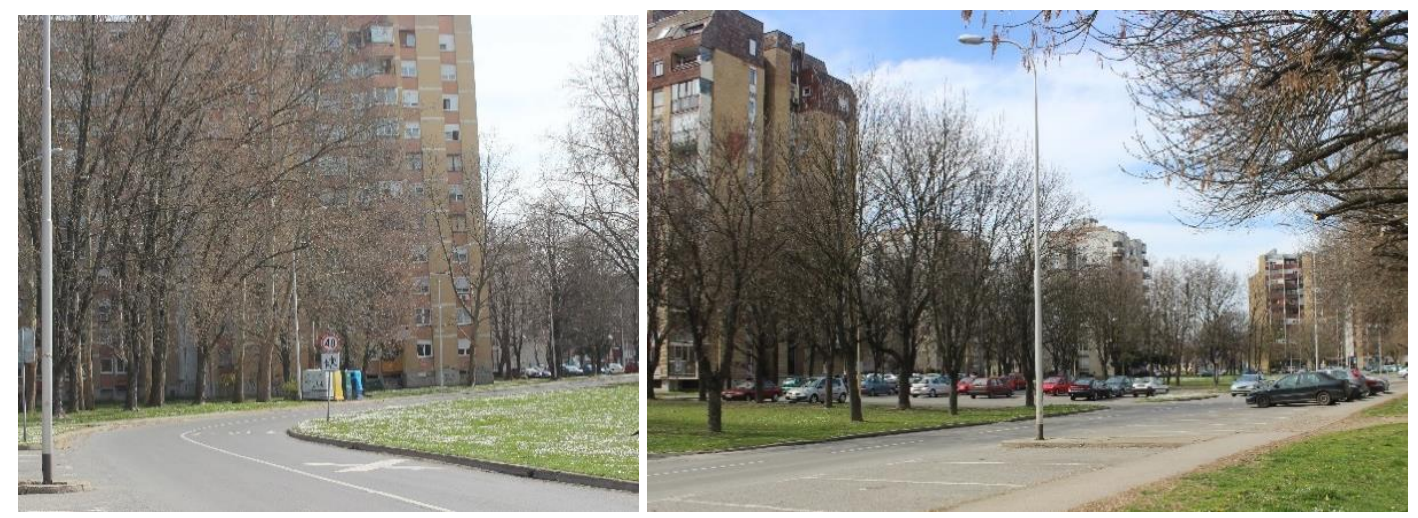

Figure 6 The settlement of Sjenjak

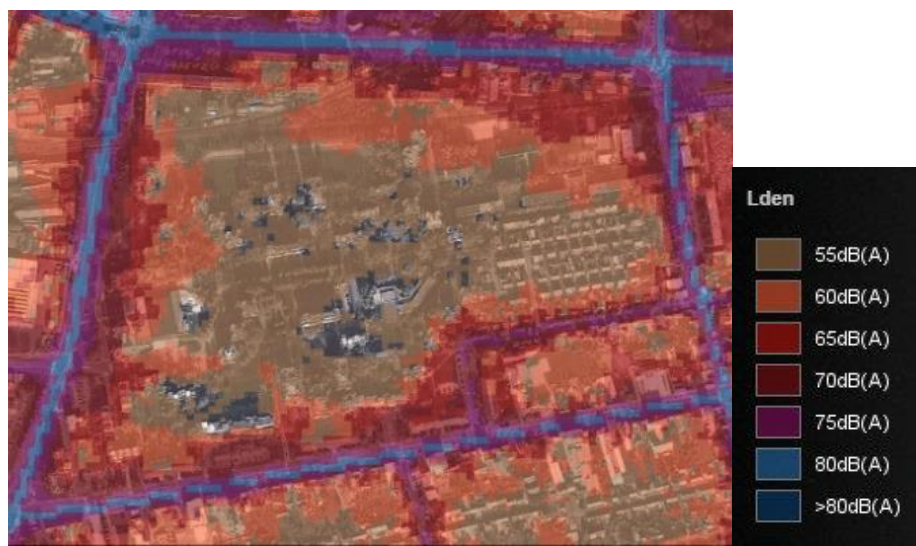

Figure 7 Noise levels in Sjenjak

\subsection{Noise abatement options in the noisiest areas}

The noise map of Osijek reveals many areas in which noise abatement measures must be implemented to reduce noise to permissible levels. However, the space and built environment should be respected, so it is not simple to choose a noise protection measure: it depends on the location and the type of traffic causing the noise. Also, sometimes it is not sufficient to use one measure, and multiple measures must be combined. For the noisiest areas on the map, listed below are the specifics of the locations and measures which might be implemented to reduce noise.

Noise levels in the city center have been reduced by limiting traffic, done through implementing pedestrian zones and one-way streets, increasing traffic around the city center, on Reisnerova, Gunduliceva, Županijska, and Hrvatske Republike Streets (Figure 8). Unfortunately, noise barriers cannot be used because of the narrow corridors between buildings and traffic areas. Roads mostly consist of traffic lanes with areas for on-street parking, sidewalks, or narrow planting strips. Constructing noise barriers would create discomfort from the feeling of enclosed space. As such, noise should be reduced here through traffic management measures, combining several measures to match the noise reduction of a barrier [9]. Reducing speed would directly reduce noise, but this speed reduction would prompt drivers who do not need to go through the city to choose different routes. The southern bypass is an excellent alternative for connecting the eastern and western ends of the city, especially since the new southern pavement will increase the capacity, speed, and safety, adequate noise protection will be constructed. Noise could be further reduced by using quiet pavement in reconstructions of traffic areas. If combining various traffic management measures would not sufficiently reduce noise, the solution may be to install sound insulation in residential buildings. 

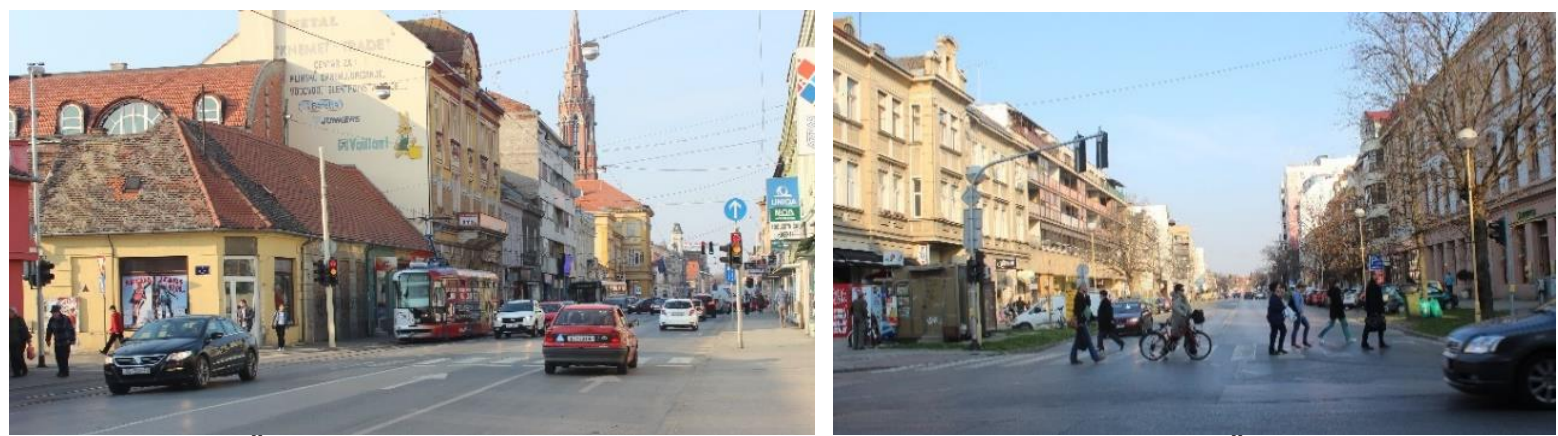

Figure 8 a) Županijska street and b) the intersection of St.Hrv.Republike with Županijska street

Along Cara Hadriana Street and European Avenue, near Osijek Clinical Hospital (Figure 9), the health care center, and the university buildings, noise levels could be reduced by choosing adequate trees and bushes of appropriate type. Extra peace and quiet near the hospital and campus could be obtained by constructing low barriers along the tram track, described in [16].

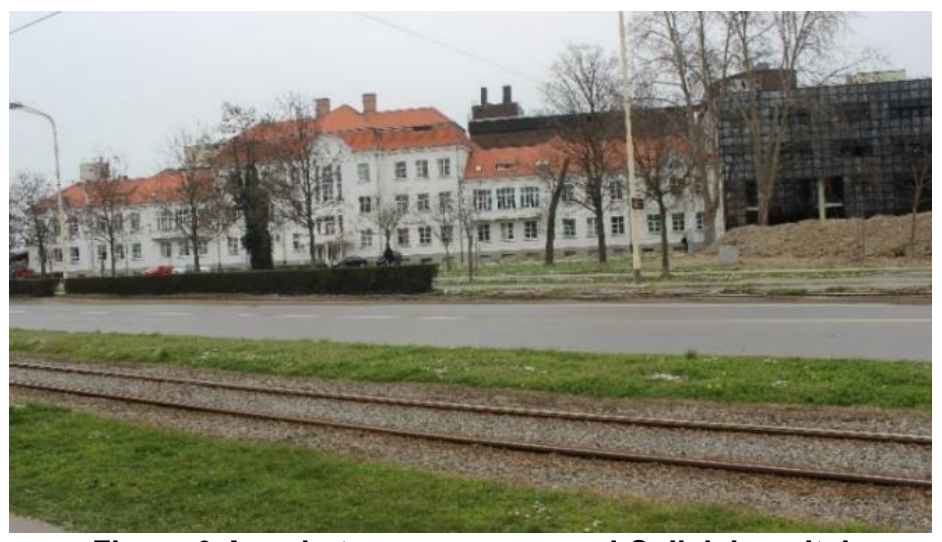

Figure 9 Area between campus and Osijek hospital

Noise near the railway station should be solved by planting vegetation and constructing barriers, which have already been constructed for safety reasons in one location (Figure 10, left). To further reduce noise, an absorbing surface could be applied to the existing barrier. Constructing barriers is especially convenient in areas where the rail passes close to residential areas. At the location shown in Figure 10 (right), as in many others, constructing barriers would be particularly appropriate because they would not only reduce noise but also improve safety by preventing uncontrolled crossing over the tracks.
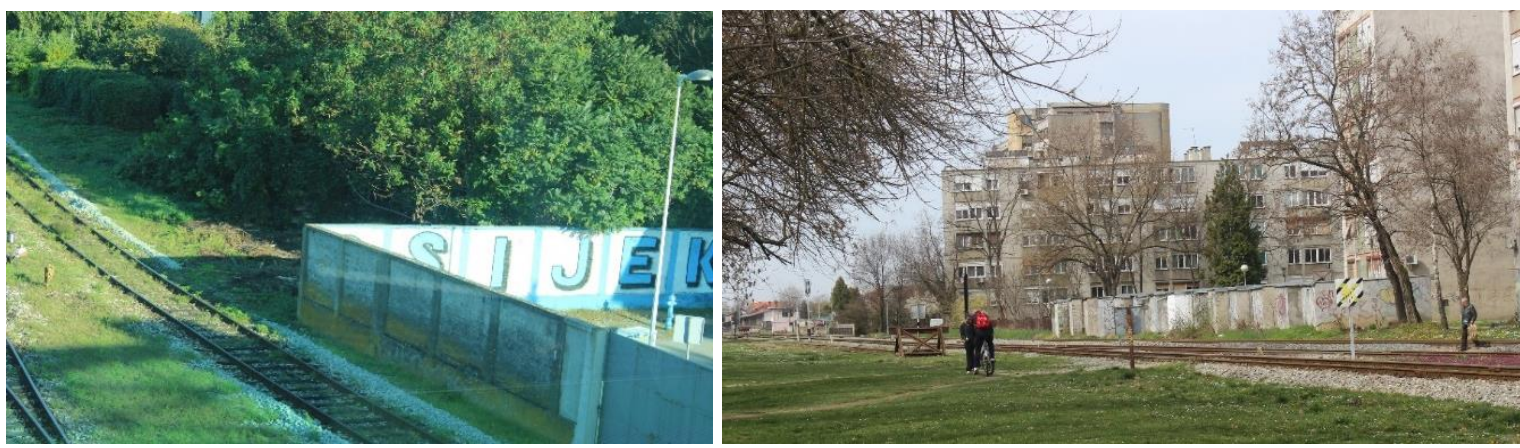

Figure 10 a) Existing barrier at railway station and b) areas along the railway where barriers are necessary 


\section{CONCLUSION}

Noise pollution is a global problem, particularly in urban areas. Noise has many negative effects, including health issues and financial losses. Thus, excessive noise must be reduced to safe, permissible levels. To reduce noise, it must be measured and mapped, showing the causes of noise and where protection is necessary. In the European Union, all cities with populations larger than 100000 are required by national legislation to make noise maps, which should include noise from all types of traffic and noise from industry.

The noise map of Osijek, created in 2014, shows that the noise levels in many locations exceed permissible limits. The major cause of this excessive noise is road and railway traffic. Osijek exemplifies the rare, unsystematic implementation of noise abatement measures in Croatian cities. In Osijek, a noise barrier has only been constructed in one location: on the edge of town. However, Because barriers have been used on highways to good effect, the examples of barriers in Zagreb, and the increasing complaints from residents, noise protection has been designed in Osijek at many locations along the southern bypass. These protective measures are being constructed as part of the construction of the pavement of the southern bypass.

Some other measures in Osijek limit noise production, but noise reduction is not their primary goal. Rather, they are are mainly traffic and technical measures, such as speed limitations or bans on certain vehicles, implemented to improve safety or increase road capacity. Also, quiet areas have been made in some parts of the city by good spatial planning and suitable vegetation.

Noise protection must be implemented in many areas in the city, especially in center and along the railroad. However, selecting measures is not easy because they must fit the built environment and limited available space while not harming the aesthetic of the city. Though they are the most effective solution, barriers cannot be constructed in some locations, so several measures of construction and traffic management must be combined to suitably reduce noise. Where possible, spatial boundaries along with trees, shrubs, and other vegetation should be used, as they benefit the environment while reducing noise.

\section{References}

[1] Piccolo, A; Plutino, D.; Cannistraro, G. 2005: Evaluation and analysis of the environmental noise of Messina, Italy, Applied Acoustics, 66, p. 447-465, http://dx.doi.org/10.1016/j.apacoust.2004.07.005

[2] Directive 2002/49/EC of the European Parliament and of the Council of 25 June 2002 Relating to the Assessment and Management of Environmental Noise.

[3] Gomzi, M. 2005: Svakodnevna buka i moguće zdravstvene posljedice, Proceeding of Simpozij "Buka i zdravlje", Zagreb, 8 December 2005., pp. 5-7 (in Croatian).

[4] Murphy, E.; King, E. A.; Rice, H. J. 2009: Estimating human exposure to transport noise in central Dublin, Ireland, Environment International, 35, pp. 298-302, http://dx.doi.org/10.1016/i.envint.2008.07.026

[5] World Health Organization 2011: "Burden of disease from environmental noise", Available from: http://www.euro.who.int__data/assets/pdf_file/0008/136466/e94888.pdf (Accessed: 22 March 2015).

[6] European Environmental Agency 2014: "Noise in Europe 2014", Available from: http://www.eea.europa.eu/publications/noise-in-europe-2014/at_download/file (Accessed: 22 March 2015).

[7] Lakušić, S.; Dragčević, V.; Rukavina, T. 2005: Mjere za smanjenje buke od prometa u urbanim sredinama, Građevinar, 57, pp. 1-9 (in Croatian).

[8] Silence: Noise Reduction in Urban Areas from Traffic and Driver Management, European Commision research, $2005 . \quad$ Available from: http://www.silenceip.org/site/fileadmin/SP_H/SILENCE_H.D2_20080816_DRI.pdf (Accessed 22 March 2015).

[9] Stančerić, I.; Dragčević, V.; Ahac, S. 2010: Toward environmental noise estimation according to the road surface characteristics and traffic volume, Technical Gazette, 17(2), pp. 191-197.

[10] Lakušić, S.; Ahac, M. 2012: Rail traffic noise and vibration mitigation measures in urban areas, Technical Gazette, 19(2), pp. 427-435.

[11] Lakušić, S. 2006: Impact of tram traffic on noise and vibrations, Electronic Journal "Technical Acoustics", http://www.ejta.org.

[12] Kotzen, B.; English, C.: Environmental noise barriers: A guide to their acoustic and visual design, Oxon: Taylor \& Francis, 2009. 
[13] Lakušić, S.; Dragčević, V.; Bartoš, D.: Traffic and industrial noise protection in urban areas - experience from Croatia, 19th International Congress on Acoustics, Madrid, 2-7 September 2007.

[14] Lakušić, S.; Ahac, M.; Ahac, S.; Stančerić, I.; Haladin I.: Noise protection of Zagreb Zoo from road and rail transport, First International Conference on Road and Rail Infrastructure, CETRA 2010, Opatija, 17-18 May 2010.

[15] Lakušić, S.; Bjegović, D.; Haladin I.; Baričević, A.; Serdar, M.: RUCONBAR- Greening the market of noise protection solutions, Second International Conference on Road and Rail Infrastructure, CETRA 2012, Dubrovnik, 7-9 May 2012.

[16] Ahac, M.; Lakušić, S.; Ahac, S.; Dragčević, V. 2013: The analysis of low noise protection barriers influence on tram traffic noise levels, Romanian Journal of Transportation Infrastructure, 2(1), pp. 1-9, http://dx.doi.org/10.1515/riti-2015-0007

[17] Zakon o zaštiti od buke, Narodne novine, 30/09.

[18] Pravilnik o načinu izrade i sadržaju karata buke i akcijskih planova te o načinu izračuna dopuštenih indikatora buke, Narodne Novine, 75/09.

[19] Pravilnik o najvišim dopuštenim razinama buke u sredini u kojoj ljudi rade i borave, Narodne novine, 145/04.

[20] "Karta buke grada Osijeka," [Online]. Available from: http://kartebuke.coin.hr/main.html?map=osijek. (Accessed 18 September 2014).

[21] IGH, Južna obilaznica grada Osijeka-Projekt zaštite od buke, Zagreb, 2011. 